\author{
A. V.Zhurakhivskyi, Dr. Sc. (Tech.), Prof., \\ orcid.org/0000-0003-2090-0711, \\ T.V. Binkevych, \\ orcid.org/0000-0002-0453-1752
}

Lviv Polytechnic National University, Lviv, Ukraine, e-mail: Taras.V.Binkevych@lpnu.ua

\title{
MODELS OF PROBABILISTIC EVALUATION OF INTENSITY OF DISCONNECTION OF OVERHEAD TRANSMISSION LINES CAUSED BY A LIGHTNING DISCHARGE
}

Purpose. Development of a mathematical and digital model for estimating the reliability of lightning protection of overhead transmission lines, taking into account random factors.

Methodology. The conducted research on reliability of lightning protection of overhead transmission lines of a voltage class $110-750 \mathrm{kV}$ involved intermediate towers of various types. The results are given in the form of curves of dangerous parameters, in absolute and relative units, as well as in the form of numerical characteristics.

Findings. Methods of analytical and statistical data processing and mathematical modelling were used. The developed mathematical and digital models allow evaluating the reliability of lightning protection of overhead transmission lines taking into account the influence of random factors. The models allow taking into account the geometric dimensions of the elements of the investigated object, the characteristics of protective devices, the operational and experimental characteristics of insulation and corona. They allow calculating curves of dangerous parameters during lightning strikes in the tower or cable in various coordinates, as well as indicators of lightning protection reliability.

Originality. Mathematical and digital models for estimating the reliability of lightning protection of overhead transmission lines have been developed, which allow taking into account a greater number of random factors and operational characteristics of the object. The model will allow analysis and systematization of random factors affecting the reliability and efficiency of lightning protection of overhead transmission lines, which will allow determining the level of influence of each of them.

Practical value. Increase in reliability and efficiency of lightning protection of overhead transmission lines due to taking into account more random factors and performance characteristics.

Keywords: overhead transmission line, lightning protection reliability, random factor, probability of impulse discharge, dangerous parameters curve, number of lightning disconnections

Introduction. Lightning strikes in overhead transmission lines (OTL) cause electrical overlays from the wire to the ground or between the wires. These discharges often pass under the action of the line voltage to the electric arc, which leads to short circuits and the complete shutdown of the transmission line. For unified power systems, such unauthorized disconnections are a dangerous phenomenon, as they can lead to these systems being dropped out of synchronism with catastrophic consequences. In addition, atmospheric overvoltages, coming from OTL to the equipment of electric stations and distribution substations, cause breakdown of isolation of electric apparatuses, transformers, switches, and others, up to the failure of automated control systems of technological processes.

The smaller the number of emergency outages due to a thunderstorm for a certain period of time is, the higher reliability of lightning protection of OTL and substations is. The intensity of lightning damage is determined by the frequency of lightning impacts and the ability of the object to resist each lightning strike.

Analysis of the recent research. The calculation of the risk of failures of power system devices associated with lightning discharges is a component of the reliability problem, for which the risk statement was proposed

(C) Zhurakhivskyi A. V., Binkevych T. V., 2018 in the IEC 71-2 isolation coordination standard [1, 2] thus

$$
P_{f}=\int_{0}^{\infty} f_{u}(u) F(u) d u
$$

where $f_{u}(u)$ is the probability density function of the lightning overvoltages stressing the apparatus; $F(u)$ is the probability distribution function of its withstand voltage.

Rémi Lambert notes that this standard can be presented using certain concepts. The formulation of risks can be reproduced according to the concept of stressstrength interference and compares the stress experienced by the component with its strength. A failure occurs when the actual stress exceeds the actual strength. Let $S$ be the stress experienced by a power system apparatus following a lightning stroke to a transmission line and $W$ be the strength of the apparatus, or its withstand capability. Let $f_{s}(s)$ and $f_{w}(w)$ be, respectively, the probability density functions for the random variables $S$ and $W$. Then, the component risk of failure, assuming that the stress $S$ and the strength $W$ are independent random variables, is given in $[1,2]$

$$
P_{f}=P(S \geq W)=\int_{0}^{\infty} f_{s}(s)\left(\int_{0}^{s} f_{w}(w) d w\right) d s=\int_{0}^{\infty} f_{s}(s) F_{w}(s) d s .
$$

ISSN 2071-2227, Naukovyi Visnyk NHU, 2018, № 2 
Note that the last equation is similar in form to the one suggested in the IEC 71-2 standard. The risk of failure can also be represented as $[1,2]$

$$
\begin{gathered}
P_{f}=\iint_{w \leq s} f_{s}(s) f_{w}(w) d s d w=\int_{0}^{\infty} f_{w}(w)\left(\int_{w}^{\infty} f_{s}(s) d s\right) d w= \\
=\int_{0}^{\infty} f_{w}(w)\left(1-F_{s}(w)\right) d w .
\end{gathered}
$$

Since the lightning-related stress $S$ experienced by the power system apparatus is a function of various input random variables that define the lightning stroke characteristics (severity, point of impact, and others), $S$ will be a random variable as well. The probability distribution of $S$, as well as its moments, will be functionally related to and may be derived from the basic random variables [3].

It is also possible to formulate a risk function using the concept of the performance function and the limit - state by selecting the basic random variables for which the distribution functions are known. This set of random variables comprises any random variable that plays a role in the failure mechanism of the component, related either to the stress experienced by the component or its strength. According to this concept, the risk of failure (emergency) can be represented in the form

$$
\begin{aligned}
P_{f}=\int_{g\left(x_{1}, x_{2}, \ldots, x_{n}\right) \leq 0} & \int f_{x_{1} \ldots x_{n}} \cdot\left(x_{1}, \ldots, x_{n}\right) d x_{1} \ldots d x_{n}= \\
= & \int_{g(x) \geq 0} f_{x}(x) d x,
\end{aligned}
$$

where $f_{x_{1} \ldots x_{n}}($.$) is the joint probability density function$ of the random variables $x_{1}, \ldots, x_{n} ; f_{x}(x)$ is the multivariate density function of the vector $X$.

Vernon Cooray notes that the term "risk" can be used in the sense of the probability with which to expect losses. For practical purposes, this term has been replaced in the recent standard [4] by the related value of losses resulting from lightning damage and expressed by the product NPL, so the expression representing the risk can be simplified to the form [5]

$$
R \approx N P L=\sum_{X=A}^{Z} N_{x} P_{x} L_{x}=\sum_{X=A}^{Z} R_{x},
$$

where $N$ is the annual number of dangerous events (lightning flashes) influencing a structure or its equipment; $P$ is the probability of damage to the structure or its equipment due to one event; $L$ is the consequent loss due to a damage relative to the total value of humans and goods of the object to be protected; $N_{x} P_{x} L_{x}$ are the values $N P L$, selected for the risk distinguished component; $R_{x}$ is the common symbol for the risk component, and $X, A$ and $Z$ are the symbols for the common respective risk components [5].

Risk analysis can also be formed based on the full charge of the lightning flash. Assuming the instantaneous voltage $u_{A}(t)$ and the instantaneous current $i_{A}(t)$ of the arrester terminal during the lightning discharge are known, the released energy in the arrester at the time instant can be computed by $[6,7]$

$$
W=\int_{0}^{t} u_{A}(t) i_{A}(t) d t .
$$

By comparing the released energy $W$ with the arrester energy absorption capability $E_{R}$, the time instant $t_{a}$ when the released energy $W$ becomes greater than $E_{R}$ could be determined. Then, the total lightning charge released until the occurrence of the arrester failure can be estimated by [7]

$$
Q_{a}=\int_{0}^{t_{a}} i(t) d t,
$$

where $Q_{a}$ is the electrical charge of lightning channel and $i(t)$ is the lightning current.

The peak current magnitude of the equivalent single wave of flash is equal to the peak current of the first stroke $I_{p}$; then $Q_{a}$ is also a function of $I_{p}$. If the arrester failure, for any given value of $I_{p}$, occurred at instant $t_{a}$, it will occur for all the great values of magnitude as well. Once the minimum value of electrical charge sufficient to cause the arrester failure is computed for each current magnitude $I_{p}$, a lightning limiting curve $D$ can be determined, with the region with the probability of arrester failure being above $[6,7]$

$$
R=\int_{D} w\left(I_{p}, Q_{a}\right) d I_{p} d Q_{a},
$$

where $w\left(I_{p}, Q_{a}\right)$ is the joint probability distribution function of $I_{p}$ and total charge $Q_{a}$ and is expressed by

$$
w\left(I_{p}, Q_{a}\right)=\frac{1}{2 \pi}\left[\frac{x^{2}+y^{2}-2 \rho x y}{2\left(1-\rho^{2}\right)}\right],
$$

where $x=\frac{\ln \left(\frac{I}{I_{m}}\right)}{\sigma_{\ln I}}$ and $y=\frac{\ln \left(\frac{Q}{Q_{m}}\right)}{\sigma_{\ln Q}} ; I_{m}(=30 \mathrm{kA})$ and $\sigma_{\ln I}(=0.53$ p.u. $)$ are median value and logarithmic value of the standard deviation of the first stroke current magnitude, respectively, $Q_{m}(=7.5 \mathrm{C})$ is the median value of total charge of flash, $\sigma_{\ln Q}(=1.04$ p.u. $)$ is the logarithmic value of standard deviation of the total charge of flash and $\rho(=0.54$ p.u. $)$ is the correlation coefficient between the first stroke current magnitude and total charge of the flash. [4].

The probability of occurrence of one undesirable event during a given time can also be calculated by the formula $[8,9]$

$$
p=\frac{1}{N_{D} T+1},
$$

where $T$ is the time for which one lightning current exceeds the maximum value (one undesirable event for the case when there is an undesirable excess of the lightning current above the limit value), years; $N_{D}$ is the number of lightning strikes per year, 1/year.

$$
N_{D}=N_{g} S_{c a} C_{D} 10^{-6},
$$


where $N_{g}$ is the density of lightning strikes in the ground, $1 /\left(\mathrm{km}^{2} /\right.$ year); $S_{c a}$ is the lightning discharge area (collection area), which is determined according to GOST R IEC 62305-2-2010, $\mathrm{m}^{2} ; C_{D}$ is the location factor that takes into account the impact of other objects.

The use of this formula will allow us to determine both the probability that the lightning current will exceed the maximum value and the likelihood that the lightning current will be less than the minimum value, which is important in determining the reliability of object protection from a direct lightning strike.

Thus, knowing the number of lightning strikes in the object $\left(N_{g}\right)$ and taking the minimum allowable time $(T)$ between two undesirable events, we determine the maximum $\left(I_{\max }\right)$ and minimal $\left(I_{\min }\right)$ lightning currents. Lightning protection system should provide protection of the object for lightning with currents in the range from $I_{\min }$ to $I_{\max }$. The probability of the appearance of lightning current in this range is, namely, the reliability of protection.

Having analyzed the existing mathematical models of lightning protection reliability, we should note that they do not have a single meteorological base, and the same models can take into account only a limited number of random factors that determine the lightning resistance of objects, which affects the accuracy of reliability indicators.

Presentation of the main research. The algorithms for calculating the probabilities of impairing the impulse stability of an OTL isolation can be reduced to one algorithm, which is based on using the $n$-fold integral over the domain $D$ on the density of the distribution of the $f(\vec{x}) n$-dimensional vector $\vec{x}$ of random variables.

$$
p=\oint \ldots \oint f(\vec{x}) \prod_{k=1}^{n} d x_{k}
$$

where as $\vec{x}$, it is necessary to take a vector of random variables that determines the lightning resistance of the object, and as an area of $D$ (closed contour of the integral), the range of values of these quantities is taken, for which the violation of the strength of the insulation occurs (the area of dangerous parameters).
We will classify the random variables that affect the probability of an impulse discharge on the OTL (Fig. 1).

In connection with the above expression (1), for the probability $p$ the breakdown of the insulation strength for one lightning strike and the random values of all values determining the reliability of the lightning protection of the object, in order to realize the numerical integration, is represented (1) in the form

$$
p=\sum_{x_{1}} \Delta F\left(x_{1}\right) \cdot \sum_{x_{2}} \Delta F\left(x_{2}\right) \ldots \sum_{x_{k}} \Delta F\left(x_{k}\right)=\prod_{k=1}^{n} \Delta F\left(x_{k}\right),
$$

where $\Delta F\left(x_{k}\right)$ is the probability that $k$ random variable will hit the given interval, which corresponds to the value of the distribution function $F\left(x_{k}\right)$ along the edges of the given interval.

Numerical integration according to (2) is realized by varying the magnitude $x_{k}$ of the elements $\Delta x_{k}$ that belong to the area of dangerous parameters. Formula (2) is valid for independent random variables, but it can be applied to correlated quantities if we use conditional distribution laws.

From the coordinates of the vector $\vec{x}$, we distinguish the quantities that form an overvoltage $u(t)$ of the random shape on the isolation of the object. These are the parameters of the lightning current wave $I, \alpha, t$, the instantaneous value of the operating voltage $u_{0}$ at the time of the lightning discharge, the distance $b$ from the lightning strike site to the ground of the line axis, which is taken into account in the interaction of the induced voltages. We group them into a separate vector $\vec{x}^{\prime}=\left(b, I, \alpha, \tau, u_{0}\right)$ and (2) is written as follows

$$
p=\sum_{b} \Delta F(b) \sum_{I} \Delta F(I) \sum_{\alpha} \Delta F(\alpha) \sum_{\tau} \Delta F(\tau) p(u) p\left(u_{0}\right)
$$

where $p(u)$ is probability of breaking the strength of the insulation of an object due to the action of the voltage $u(t)$ on it, formed by the components of the vector $\vec{x}^{\prime}$ for fixed values.

The probability $p(u)$ is determined by the distribution of quantities that take into account the meteorological conditions, the insulation state, the normal scat-

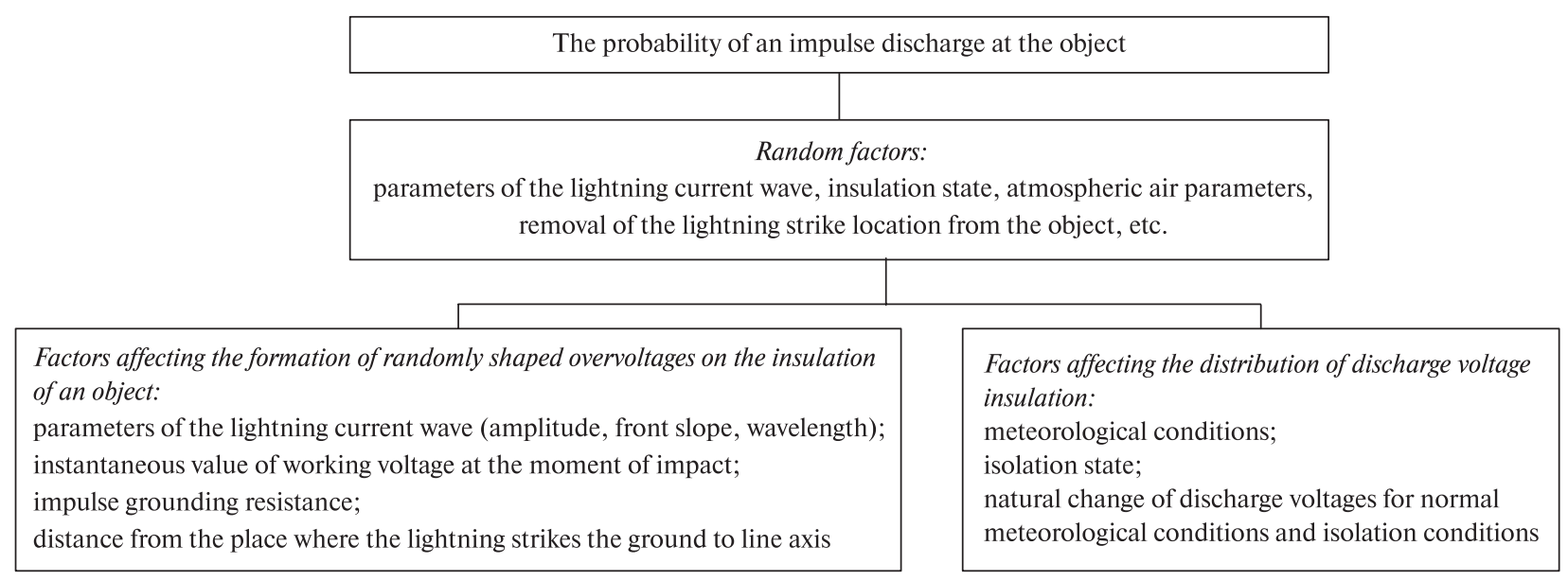

Fig. 1. Systematization of random factors that affect the probability of an impulse discharge on the OTL 
ter of the discharge voltages, and the parameters of the acting voltage $u(t)$.

The influence of the operating voltage $u_{0}$ is taken into account by dividing the period of the operating voltage into $n$ intervals. We calculate the instantaneous value of the operating voltage $u_{0}$, the insulation voltage $u(t)=$ $=u_{0}+u(t)$, and the probability $p(u)^{\prime}$ for each of the three phases for all $n$ intervals. If $p(u)^{\prime}=1$ for $m$ intervals for at least one phase, then the probability of breaking the insulation strength of the object taking into account the influence of the operating voltage $p\left(u, u_{0}\right)$ will be equal to the ratio $\mathrm{m} / \mathrm{n}$.

We have implemented such a mathematical model programmatically. To simplify the preparation of data for calculation, changing the parameters of the experiment, presentation of the results in a convenient form, a program interface was developed.

The calculation results are displayed in graphical form and contain three blocks of information: "Voltsecond characteristic", "Curves of dangerous parameters when striking the tower" and "Curves of dangerous parameters when striking a rope". It should be noted that the user is given the opportunity to choose the representation of graphs in different coordinates, that is, in coordinates $A=f(I)$ and $P A=f(P I)$. It should also be pointed out that the unit of measurement of the steepness of the front ( $A-$ axis of ordinates) on the graphs is $[\mathrm{kA} / \mu \mathrm{s}]$, and $[\mathrm{kA}]$ is the unit of current measurement $(I$ is the abscissa axis).

The results window contains a block that displays information on the specific number of OTL outages from lightning strikes to rope, tower, wire, and the total specific number of lightning outages and the absolute number of lightning outages per year.

We present the results of calculations of reliability of lightning protection for OTL of a voltage class of $500 \mathrm{kV}$ made by intermediate supports of type PB-2 (Figs. 2-4) and the results of calculations of lightning protection reliability for OTL of the voltage class $110-750 \mathrm{kV}$ made by intermediate towers of different types (Table).

Conclusions. Having analyzed the existing models of the probabilistic estimation of the intensity of OTL outages, we should note that a significant drawback is that they can only take into account a limited number of ran-

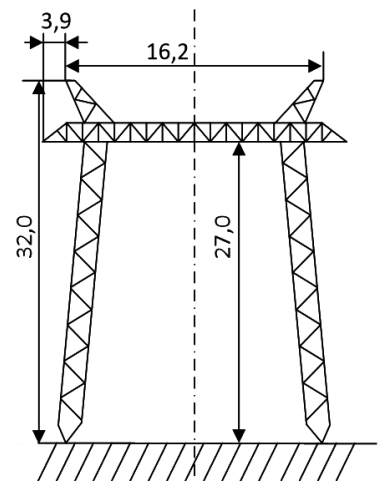

$a$
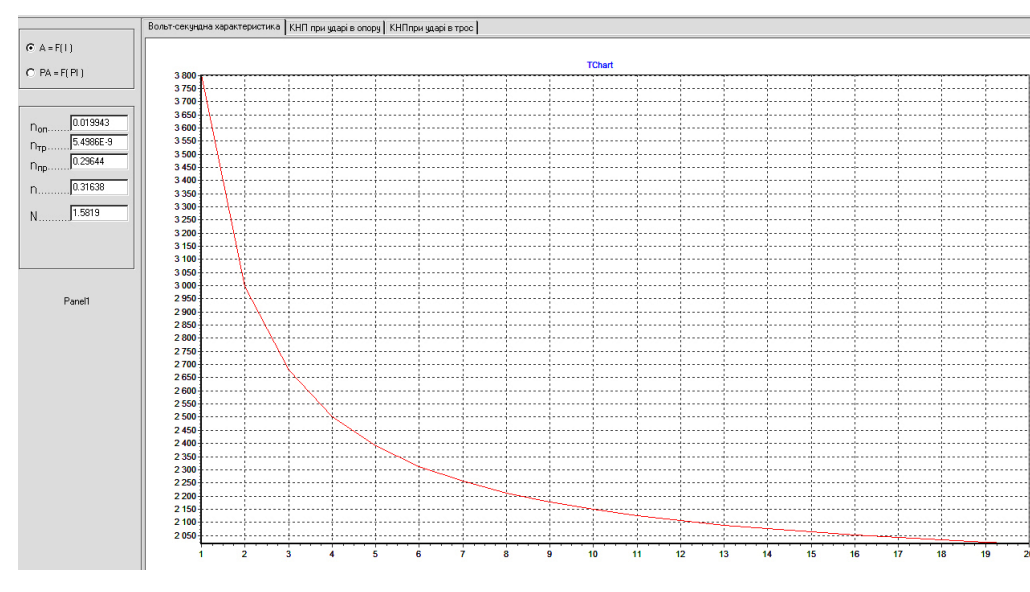

$b$

Fig. 2. Characteristic of the researching tower and linear insulation of OTL:

$a$ - Sketch of intermediate tower type $P B-2 ; b$ - recalculated volt-second characteristic of insulation

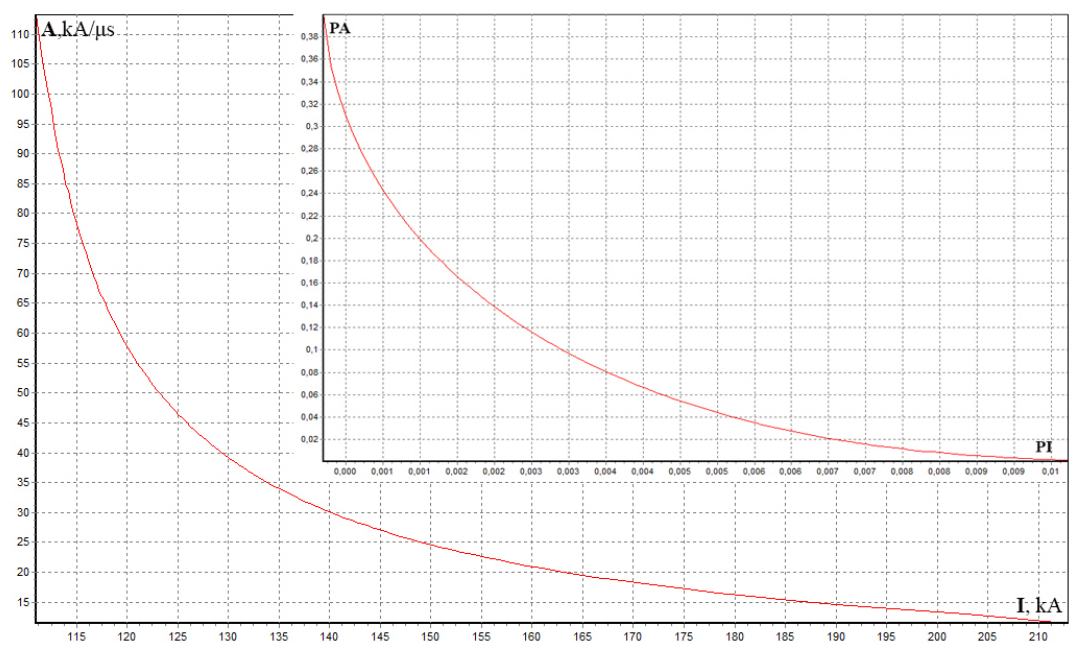

Fig. 3. Curves of dangerous parameters due to lightning strike in the tower in coordinates $A=f(I)$ and $P A=f(P I)$ 
ङ

\begin{tabular}{|c|c|c|c|c|c|c|c|c|c|c|c|c|c|c|c|c|c|c|c|c|c|c|c|}
\hline \multirow{4}{*}{$\begin{array}{l}\frac{3}{a} \\
\frac{1}{n}\end{array}$} & 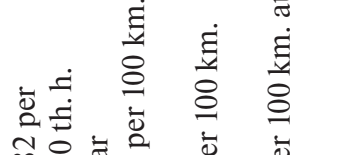 & $\Xi$ & @i & $\grave{2}$ & & & 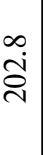 & $\begin{array}{l}\circ \\
\stackrel{0}{\circ} \\
\stackrel{0}{=}\end{array}$ & $\begin{array}{l}\dot{0} \\
\stackrel{2}{2}\end{array}$ & $\stackrel{\sim}{\tilde{\sigma}}$ & $\stackrel{\circ}{\stackrel{9}{9}}$ & $\begin{array}{l}\infty \\
\dot{0} \\
\stackrel{\infty}{0}\end{array}$ & $\begin{array}{l}n \\
2 \\
\infty \\
\infty\end{array}$ & $\begin{array}{l}\underset{\dot{ \pm}}{ \pm} \\
\stackrel{1}{*}\end{array}$ & $\mid \begin{array}{l}0 \\
\dot{\Phi} \\
\underline{\infty}\end{array}$ & $\vec{a}$ & $\begin{array}{c}m \\
\infty \\
= \\
=\end{array}$ & 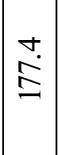 & $\stackrel{m}{\stackrel{2}{=}}$ & $\begin{array}{c}n \\
\tilde{N} \\
\end{array}$ & $\hat{I}$ & 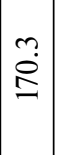 & $\overrightarrow{0}$ \\
\hline & 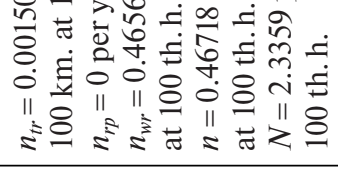 & $\frac{0}{3}$ & $\stackrel{+}{\stackrel{+}{9}}$ & $\underset{c}{5}$ & & $\begin{array}{l}R \\
0 \\
i \\
\sim\end{array}$ & $\frac{n}{\dot{m}}$ & $\begin{array}{l}\vec{N} \\
\ddot{m}\end{array}$ & $\begin{array}{l}\infty \\
\infty \\
\dot{\infty} \\
\dot{\rho}\end{array}$ & $\begin{array}{l}\tilde{n} \\
\infty \\
\infty\end{array}$ & $\begin{array}{l}\stackrel{\ell}{0} \\
\dot{\sigma}\end{array}$ & $\begin{array}{l}\triangleright \\
\stackrel{+}{+} \\
\end{array}$ & $\begin{array}{l}\hat{n} \\
\dot{q} \\
+\end{array}$ & 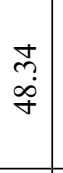 & $\mid \begin{array}{l}\infty \\
\infty \\
\dot{n}\end{array}$ & $\begin{array}{l}0 \\
i \\
i n \\
n\end{array}$ & $\begin{array}{l}\tilde{n} \\
\tilde{n}\end{array}$ & $\mid \begin{array}{l}\infty \\
\\
i n\end{array}$ & 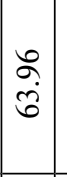 & $\begin{array}{l}0 \\
0 \\
0 \\
0\end{array} \mid$ & $\begin{array}{l}\mathcal{C}^{\prime} \\
\stackrel{+}{+}\end{array}$ & \begin{tabular}{|c}
$\stackrel{\infty}{m}$ \\
$\dot{\infty}$
\end{tabular} & $\begin{array}{l}\infty \\
\infty \\
\text { a }\end{array}$ \\
\hline & & $\Sigma$ & స్ & $\bar{\Xi}$ & & $\begin{array}{l}2 \\
\hat{\sigma} \\
0 \\
0\end{array}$ & 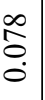 & $\begin{array}{l}\stackrel{0}{0} \\
\stackrel{0}{0}\end{array}$ & $\begin{array}{l}\tilde{2} \\
0 \\
0\end{array}$ & 守 & $\begin{array}{l}0 \\
\tilde{o} \\
0 \\
0\end{array}$ & $\begin{array}{l}\widehat{\Xi} \\
\dot{0}\end{array}$ & $\begin{array}{l}\dot{\Xi} \\
\grave{0} \\
\dot{0}\end{array}$ & $\begin{array}{l}\overrightarrow{\overrightarrow{0}} \\
\dot{0}\end{array}$ & $\begin{array}{l}0 \\
0 \\
0 \\
0\end{array}$ & $\begin{array}{l} \pm \\
\dot{0} \\
\dot{0}\end{array}$ & $\begin{array}{l}0 \\
0 \\
0 \\
0\end{array}$ & $\mid \begin{array}{l}\infty \\
\stackrel{0}{0} \\
\dot{0}\end{array}$ & $\mid \begin{array}{l}0 \\
\vdots \\
0 \\
0\end{array}$ & 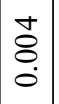 & $\begin{array}{l}\tilde{8} \\
\dot{0} \\
\dot{0}\end{array} \mid$ & $\mid \begin{array}{c}\overrightarrow{0} \\
0 \\
0\end{array}$ & $\begin{array}{l}0 \\
0 \\
\text { ț } \\
\text { ton }\end{array}$ \\
\hline & & $\bar{\Sigma}$ & 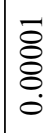 & ఏे & 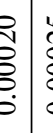 & 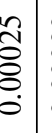 & $\begin{array}{c}0 \\
\tilde{\sigma} \\
\vdots \\
\vdots \\
\dot{0}\end{array}$ & $\begin{array}{l}\tilde{\tilde{o}} \\
\tilde{\delta} \\
\dot{0}\end{array}$ & $\begin{array}{l}0 \\
0 \\
0 \\
0 \\
0 \\
0\end{array}$ & $\begin{array}{l}1 \\
0 \\
0 \\
0 \\
0 \\
0\end{array}$ & 章 & $\mid \begin{array}{l}n \\
2 \\
0 \\
\vdots \\
0\end{array}$ & $\mid \begin{array}{l}0 \\
0 \\
\vdots \\
0 \\
\vdots \\
0\end{array}$ & \begin{tabular}{|l|}
1 \\
0 \\
$\vdots$ \\
0 \\
0
\end{tabular} & $\mid \begin{array}{l}0 \\
\vdots \\
\vdots \\
\vdots \\
0\end{array}$ & $\begin{array}{l}n \\
\hat{o} \\
\vdots \\
0 \\
0\end{array}$ & $\begin{array}{l}0 \\
0 \\
0 \\
0 \\
0\end{array}$ & $\mid \begin{array}{l}n \\
0 \\
0 \\
\vdots \\
0 \\
0\end{array}$ & $\mid \begin{array}{c}0 \\
\grave{े} \\
0 \\
0\end{array}$ & $\mid$ & $\begin{array}{l}0 \\
\vdots \\
\vdots \\
0\end{array}$ & $\mid \begin{array}{c}\bar{\sigma} \\
\vdots \\
\dot{0}\end{array}$ & $\stackrel{ }{8}$ \\
\hline \multirow{4}{*}{$\frac{3}{0}$} & & $\Xi$ & 离 & 告 & & $\begin{array}{l}0 \\
\infty \\
0 \\
m\end{array}$ & $\begin{array}{l}\mathfrak{n} \\
\mathfrak{n} \\
\end{array}$ & $\stackrel{\widehat{\Xi}}{\widehat{\Xi}}$ & 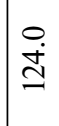 & 宅 & $\stackrel{\infty}{\varrho}$ & $\widehat{\grave{I}}$ & $\begin{array}{l}0 \\
\stackrel{0}{\Xi}\end{array}$ & $\begin{array}{l}0 \\
\dot{0} \\
\dot{0} \\
0\end{array}$ & $\hat{\mathscr{0}}$ & $\begin{array}{c}0 \\
\dot{0} \\
0\end{array}$ & $\begin{array}{l}\stackrel{+}{\oplus} \\
\stackrel{0}{0}\end{array}$ & $\frac{a}{\dot{a}}$ & $\begin{array}{l}\overrightarrow{0} \\
\dot{8}\end{array}$ & $\left|\begin{array}{l}0 \\
0 \\
2\end{array}\right|$ & $\begin{array}{l}\infty \\
2 \\
2 \\
2\end{array}$ & $\mid$\begin{tabular}{l}
$f$ \\
\multirow{2}{\alpha}{}
\end{tabular} & $\vec{m}$ \\
\hline & 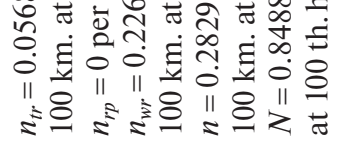 & $\frac{0}{3}$ & $\stackrel{\Im}{\stackrel{I}{=}}$ & $\begin{array}{l}\bar{\alpha} \\
2 \\
2\end{array}$ & & 文 & $\begin{array}{l}n \\
\dot{n} \\
\dot{\omega}\end{array}$ & $\stackrel{\infty}{?}$ & $\stackrel{0}{9}$ & $\mid \begin{array}{l}\Omega \\
\infty \\
\stackrel{i}{1}\end{array}$ & 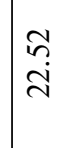 & $\frac{\stackrel{9}{\vec{\nu}}}{\dot{\omega}}$ & $\begin{array}{l}\overline{1} \\
\infty \\
\sim\end{array}$ & $\left|\begin{array}{l}\infty \\
m \\
i \\
\dot{m}\end{array}\right|$ & $\left|\begin{array}{c}\mathbb{i} \\
i \\
\tilde{i}\end{array}\right|$ & $\left|\begin{array}{l}\infty \\
m \\
i n \\
m\end{array}\right|$ & $\begin{array}{l}\vec{\sigma} \\
\dot{\nabla} \\
\dot{m}\end{array} \mid$ & $\begin{array}{l}n \\
\tilde{z} \\
\dot{\gamma}\end{array}$ & $\left|\begin{array}{c}\tilde{b} \\
\dot{f}\end{array}\right|$ & $\begin{array}{l}\tilde{N} \\
\tilde{n} \\
n\end{array}$ & $\begin{array}{l}\tilde{O} \\
\mathbb{d}\end{array}$ & $\mid \begin{array}{l}\vec{b} \\
\dot{i}\end{array}$ & mై \\
\hline & & $\Sigma$ & 亭 & בú & & $\begin{array}{c}\frac{v}{m} \\
\overrightarrow{0}\end{array}$ & 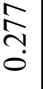 & 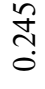 & $\stackrel{0}{\sim}$ & $\underset{0}{0}$ & $\frac{16}{6}$ & $\underset{\overbrace{}}{\overparen{0}}$ & $\begin{array}{l}2 \\
0 \\
0\end{array}$ & $\mid \begin{array}{l}\infty \\
0 \\
0 \\
0\end{array}$ & $\left|\begin{array}{l}\tilde{0} \\
0 \\
0\end{array}\right|$ & $\mid \begin{array}{l}\hat{2} \\
\hat{0} \\
\dot{0}\end{array}$ & \begin{tabular}{l}
0 \\
\multirow{1}{0}{} \\
$\dot{0}$
\end{tabular} & $\mid \begin{array}{l}0 \\
\tilde{0} \\
0 \\
0\end{array}$ & $\left|\begin{array}{l}0 \\
0 \\
0 \\
0\end{array}\right|$ & $\left|\begin{array}{c}\infty \\
0 \\
0\end{array}\right|$ & $\begin{array}{l}\hat{8} \\
\dot{0}\end{array}$ & $\mid \begin{array}{c}\tilde{\delta} \\
\dot{0}\end{array}$ & ळ. \\
\hline & & $\bar{\Sigma}$ & छे. & $\mid \tilde{g}$ & & $\begin{array}{l}0 \\
8 \\
0 \\
0\end{array}$ & $\begin{array}{l}\hat{\delta} \\
\dot{\delta} \\
\dot{0}\end{array}$ & $\begin{array}{l}\stackrel{8}{\circ} \\
\stackrel{0}{0}\end{array}$ & $\begin{array}{l}\hat{\theta} \\
\dot{0}\end{array}$ & $\mid \begin{array}{l}\infty \\
0 \\
0\end{array}$ & 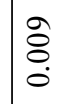 & $\begin{array}{l}\overrightarrow{\bar{o}} \\
\dot{0}\end{array}$ & $\begin{array}{l}a \\
0 \\
0 \\
0\end{array}$ & $\mid \begin{array}{l}m \\
0 \\
0\end{array}$ & $\begin{array}{l}\vec{t} \\
\dot{0} \\
\dot{0}\end{array}$ & $\begin{array}{l}n \\
0 \\
0 \\
0\end{array}$ & $\begin{array}{l}0 \\
0 \\
0 \\
0\end{array}$ & $\begin{array}{l}\hat{a} \\
\dot{0} \\
\dot{0}\end{array}$ & $\mid \begin{array}{l}\infty \\
0 \\
0 \\
0\end{array}$ & $\begin{array}{l}\vec{\partial} \\
\dot{0}\end{array}$ & $\begin{array}{l}\vec{\delta} \\
\stackrel{\circ}{ }\end{array}$ & $\mid \begin{array}{c}\tilde{O} \\
0 \\
0\end{array}$ & 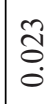 \\
\hline \multirow{4}{*}{$\begin{array}{l}\vec{y} \\
\overrightarrow{\mathbb{N}}\end{array}$} & 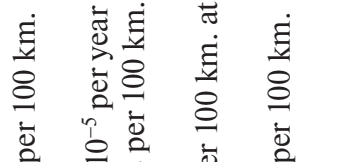 & $\Xi$ & f & $\mid \begin{array}{ll}1 \\
7 \\
8 \\
8\end{array}$ & & $\begin{array}{l}\dot{m} \\
\dot{R} \\
\dot{R}\end{array}$ & 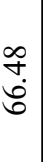 & $\underset{\Theta}{\stackrel{\Xi}{\sigma}}$ & $\begin{array}{l}\stackrel{i}{1} \\
\stackrel{8}{8}\end{array}$ & $\begin{array}{l}0 \\
i n \\
i n \\
0\end{array}$ & $\begin{array}{l}\infty \\
i n \\
i n\end{array}$ & $\begin{array}{l}\bar{\sigma} \\
\dot{n}\end{array}$ & $\begin{array}{l}\overrightarrow{\dot{a}} \\
\vec{n}\end{array}$ & $\begin{array}{l}\stackrel{n}{a} \\
\dot{g}\end{array}$ & $\mid \begin{array}{r}\stackrel{f}{\sim} \\
\stackrel{f}{f}\end{array}$ & $\begin{array}{l}\vec{\infty} \\
\dot{\sigma} \\
\dot{\sigma}\end{array}$ & $\begin{array}{l}\stackrel{\Re}{j} \\
\dot{f}\end{array}$ & $\begin{array}{l}\hat{\infty} \\
\tilde{J} \\
\mathcal{f}\end{array}$ & $\mid \begin{array}{c}\tilde{n} \\
\vec{F}\end{array}$ & 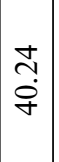 & & $\mid \begin{array}{c}n \\
\infty \\
\dot{m} \\
\dot{m}\end{array}$ & 站 \\
\hline & 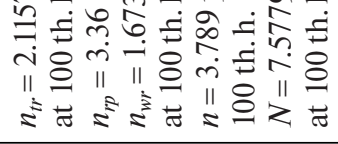 & $\frac{0}{\psi_{j}^{3}}$ & 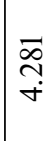 & $\mid \begin{array}{ll}n \\
\vdots \\
i \\
\text { in }\end{array}$ & $\frac{\varepsilon}{i}$ & 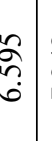 & 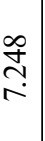 & $\underset{\infty}{\stackrel{+}{c}}$ & $\frac{n}{a}$ & $\vec{\alpha}$ & $\stackrel{\Xi}{=}$ & 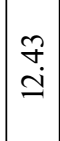 & $\begin{array}{l}q \\
\dot{q} \\
\dot{q}\end{array}$ & $\mid \begin{array}{l}0 \\
0 \\
2 \\
2\end{array}$ & 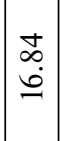 & $\begin{array}{l}\Omega \\
\hat{\infty} \\
\infty\end{array} \mid$ & 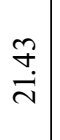 & $\begin{array}{l}\infty \\
n \\
\stackrel{\sim}{\sim}\end{array}$ & in & 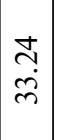 & $\begin{array}{l}\stackrel{t}{N} \\
\dot{q}\end{array}$ & $\mid \begin{array}{l}2 \\
\dot{b} \\
\dot{q} \\
\end{array}$ & in \\
\hline & $\sim$ & $\Sigma$ & & $\tilde{c}$ & : & है & ?ִ. & กิ & $\stackrel{\infty}{0}$ & $\stackrel{n}{q}$ & F & $\bar{n}$ & $\begin{array}{l}+ \\
m \\
0\end{array}$ & $\ddot{0}$ & 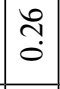 & กิ่ & $\frac{\infty}{0}$ & $\frac{ \pm}{0}$ & $=$ & $\begin{array}{l}0 \\
0 \\
0\end{array}$ & $\begin{array}{l} \pm \\
\dot{0} \\
0\end{array}$ & $\begin{array}{l}\tilde{\sigma} \\
0 \\
0\end{array}$ & $\ddot{0}$ \\
\hline & & $\overline{0}$ & 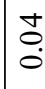 & & Se & $\begin{array}{ll}0 \\
: \\
0\end{array}$ & 㝘. & $\stackrel{\infty}{\infty}$ & oे & $\stackrel{0}{0}$ & $=$ & $\stackrel{7}{0}$ & $\stackrel{9}{0}$ & $\stackrel{0}{0}$ & $\stackrel{n}{0}$ & $\frac{0}{0}$ & $\stackrel{5}{0}$ & $\stackrel{\infty}{0}$ & $\frac{9}{0}$ & స̂̀ & $\overline{\widetilde{o}}$ & กิ & $\stackrel{\overbrace{}}{3}$ \\
\hline
\end{tabular}

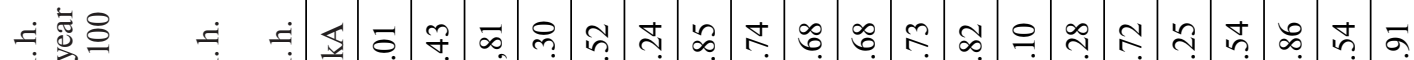

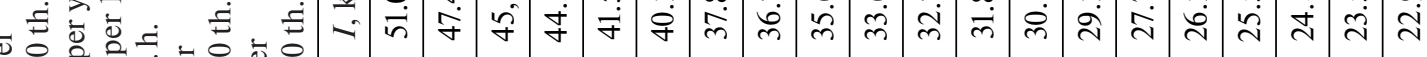

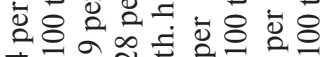

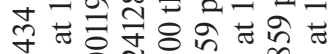

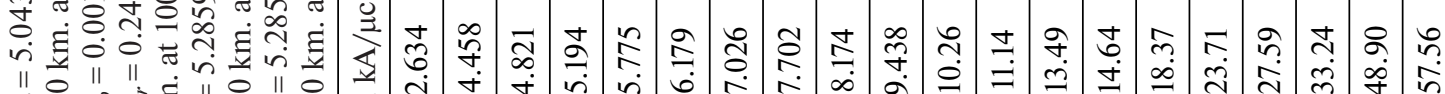

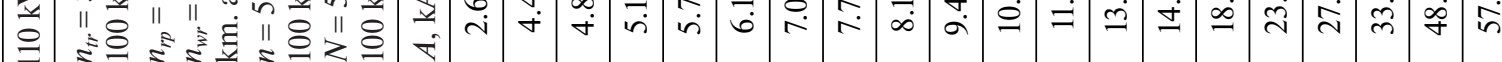

\begin{tabular}{|c|c|c|c|c|c|c|c|c|c|c|c|c|c|c|c|c|c|c|c|c|c|}
\hline & & $\begin{array}{l}\vec{\infty} \\
0 \\
0\end{array}$ & $\stackrel{R}{0}$ & $\begin{array}{l}\infty \\
0 \\
0\end{array}$ & : & $\mid \begin{array}{l}0 \\
0 \\
0\end{array}$ & $\overrightarrow{0}$ & $\begin{array}{l}\hat{n} \\
0 \\
0\end{array}$ & $\stackrel{+}{n}$ & ñ & $\stackrel{f}{\circ}$ & $\mid \begin{array}{l}+ \\
\dot{0}\end{array}$ & $\underset{\dot{\sigma}}{\overrightarrow{0}}$ & $\begin{array}{l} \pm \\
\stackrel{0}{0} \\
0\end{array}$ & $\vec{m}$ & ָָ & & $\stackrel{=}{\circ}$ & $\stackrel{0}{0}$ & & \\
\hline & & $\stackrel{m}{0}$ & $\stackrel{2}{0}$ & $\frac{0}{0}$ & $\stackrel{5}{0}$ & $\frac{9}{0}$ & ָุ & 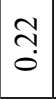 & $\stackrel{\widetilde{0}}{0}$ & 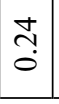 & $\stackrel{\text { İ }}{0}$ & $\begin{array}{c}\hat{y} \\
\tilde{0}\end{array}$ & 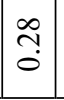 & $\stackrel{0}{0}$ & $\bar{m}$ & $\stackrel{m}{\tilde{0}}$ & & & ñ. & & \\
\hline
\end{tabular}




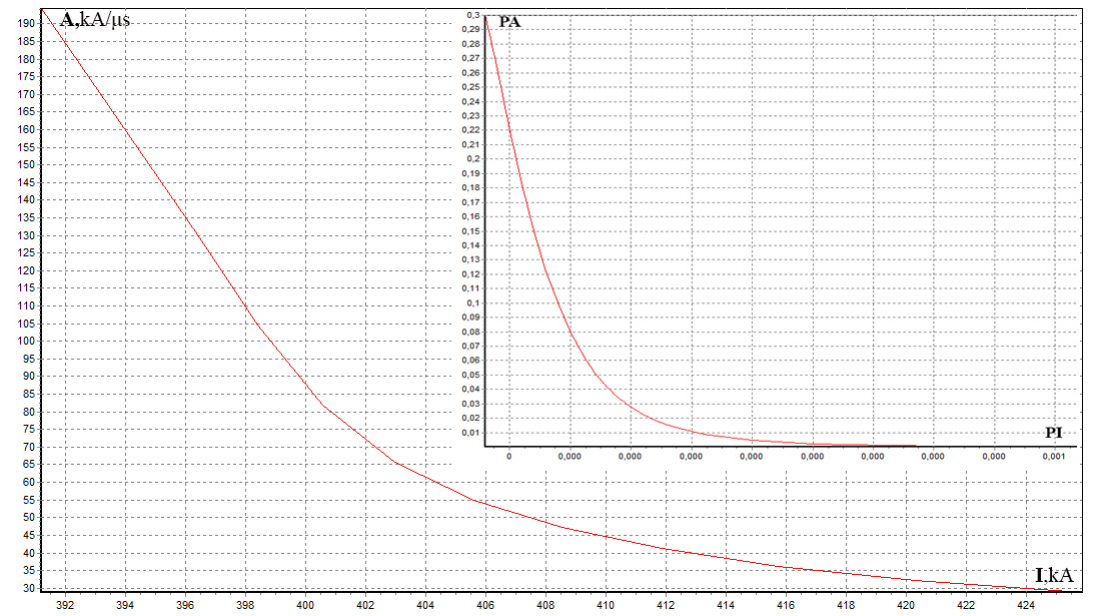

Fig. 4. Curves of dangerous parameters for lightning strike in the rope in coordinates $A=f(I)$ and $P A=f(P I)$

dom factors that determine the lightning resistance of objects, and this affects the accuracy of the reliability indicators and makes it more difficult to optimize the lightning protection schemes. The proposed model takes into account all the random variables that determine the lightning resistance of the OTL, and the developed methods for their calculation ensure adequacy and compliance with natural processes.

Input data for calculating the reliability of lightning protection of OTL include the geometric dimensions of the OTL, the characteristics of protective apparatus, operational and experimental characteristics of insulation and corona.

The accuracy of the lightning protection model can be justified formally. Undoubtedly, the criterion of accuracy should be considered as the correspondence of the results of calculations to the results of the operational experience.

\section{References.}

1. IEEE Standards Association. IEEE Guide for the Application of Insulation Coordination - 1313.2-1999, 2005 (in force) [online]. Available at: <http://ieeexplore. ieee.org/document/806063/> [Accessed 24 May 2017]. 2. Xiong, X., Wang, J. and Weng, S., 2014. Qing Yang Short-Term Reliability Evaluation of Transmission System Using Lightning Strike Probability Prediction. Journal of Power and Energy Engineering, 2, pp. 647-655. 3. Romualdo-Torres, C., Ramirez-Gonzaez, M. and Escamilla-Paz, A., 2016. Lightning outage transmission line reliability improvement with surge arresters. In: Transmission and Distribution Conference and Exposition (T\&D), 2016 IEEE/PES [e-journal]. DOI: 10.1109/ TDC.2016.7519847.

4. International Electrotechnical Commission, 2010. International Standard IEC 62305-2. 2010. Protection against lightning. Part $2-$ Risk management (in force), [online]. Available at: <https://webstore.iec.ch/publication/6794> [Accessed 10 November 2017].

5. Cooray, V., 2015. An Introduction to Lightning. London: The Institution of Engineering and Technology.

6. Shariatinasab, R., Ajri, F. and Daman-Khorshid, H., 2013. Probabilistic evaluation of failure risk of transmis- sion line surge arresters caused by lightning flash. IET Generation, Transmission \& Distribution.

7. Paladian, F., Bonnet, P., Lallechere, S., Xemard, A. and Miry, C., 2014. On the numerical analysis of lightning effect on power installations. In: CIGRE International Colloquium on Lightning and Power Systems, INSA Lyon - France.

8. STO RZhD 08.026-2015. Protection from atmospheric and switching overvoltages. Lightning arresters and equipment earthing devices. Technical requirements (in force).

9. Fedor Shkrabets, F. and Kyrychenko, M., 2013. Methods of improving the reliability of distribution networks $6-35 \mathrm{kV}$. Electric power engineering and control systems 2013 (EPECS-2013) [pdf], pp. 72-75. Available at: <http://ena.lp.edu.ua:8080/bitstream/ntb/26854/ 1/024-072-075.pdf> [Accessed 16 September 2017].

\section{Моделі ймовірнісної оцінки інтенсивності вимкнень повітряних ліній електропересилання від розрядів блискавки}

\section{А. В. Журахівський, Т. В. Бінкевич}

Національний університет „Львівська політехніка“, м. Львів, Україна, e-mail: Taras.V.Binkevych@lpnu.ua

Мета. Створення математичної й цифрової моделі оцінки надійності грозозахисту повітряних ліній з урахуванням випадкових факторів.

Методика. Проведені дослідження надійності грозозахисту повітряних ліній електропересилання класу напруг 110-750 кВ, виконаних на проміжних опорах різного типу. Результати наведені у вигляді кривих небезпечних параметрів, в абсолютних і відносних одиницях, а також у вигляді числових характеристик.

Результати. Використані методи аналітичної й статистичної обробки даних, математичного моделювання. Створені математична й цифрова моделі дозволяють здійснювати оцінку надійності грозозахисту повітряних ліній електропересилання з урахуванням впливу випадкових факторів. Моделі дозволяють урахувати геометричні розміри елементів до- 
сліджуваного об’єкта, характеристики захисних апаратів, експлуатаційні та експериментальні характеристики ізоляції й корони. Вони дозволяють розрахувати криві небезпечних параметрів під час ударів блискавки в опору чи трос у різних координатах, а також показники надійності грозозахисту.

Наукова новизна. Створено математичну й цифрову моделі оцінки надійності грозозахисту повітряних ліній електропересилання, що дозволяють урахувати більшу кількість випадкових факторів і експлуатаційних характеристик об'єкта. Модель дозволить проводити аналіз і систематизацію випадкових факторів, які впливають на надійність і ефективність грозозахисту повітряних ліній електропересилання, що дасть змогу визначити рівень впливовості кожного з них.

Практична значимість. Підвищення надійності та ефективності грозозахисту повітряних ліній електропересилання за рахунок урахування більшої кількості випадкових факторів і експлуатаційних характеристик.

Ключові слова: повітряна лінія електропересилання, надійність грозозахисту, випадковий фактор, імовірність імпульсного розряду, крива небезпечних параметрів, число грозових відключень

\section{Модели вероятностной оценки интенсивности выключения воздушных линий электропередачи от разрядов молнии}

\section{А. В. Жураховский, Т. В. Бинкевич}

Национальный университет „Львовская политехника“, г. Львов, Украина, e-mail: Taras.V.Binkevych@lpnu.ua

Цель. Создание математической и цифровой модели оценки надежности грозозащиты воздушных линий с учетом случайных факторов.

Методика. Проведенные исследования надежности грозозащиты воздушных линий электропередачи класса напряжения 110-750 кВ выполнены на промежуточных опорах различного типа. Результаты приведены в виде кривых опасных параметров, в абсолютных и относительных единицах, а также в виде числовых характеристик.

Результаты. Использованы методы аналитической и статистической обработки данных, математического моделирования. Созданные математическая и цифровая модели позволяют осуществлять оценку надежности грозозащиты воздушных линий электропередачи с учетом влияния случайных факторов. Модели позволяют учесть геометрические размеры элементов исследуемого объекта, характеристики защитных аппаратов, эксплуатационные и экспериментальные характеристики изоляции и короны. Они позволяют рассчитать кривые опасных параметров во время ударов молнии в опору или трос в различных координатах, а также показатели надежности грозозащиты.

Научная новизна. Созданы математическая и цифровая модели оценки надежности грозозащиты воздушных линий электропередачи, которые позволяют учесть большее количество случайных факторов и эксплуатационных характеристик объекта. Модель позволит проводить анализ и систематизацию случайных факторов, влияющих на надежность и эффективность грозозащиты воздушных линий электропередачи, что позволит определить уровень влияния каждого из них.

Практическая значимость. Повышение надежности и эффективности грозозащиты воздушных линий электропередачи за счет учета большего количества случайных факторов и эксплуатационных характеристик.

Ключевые слова: воздушная линия электропередачи, надежность грозозащиты, случайный фактор, вероятность импульсного разряда, кривая опасных параметров, число грозовых отключений

Рекомендовано до публікації докт. техн. наук Ю.О.Варецьким. Дата надходження рукопису 10.02.17. 